\title{
A IMPORTÂNCIA DO PROFESSOR NA APLICAÇÃO DO INSTITUTO DA REMIÇÃO NO CUMPRIMENTO DA PENA.
}

Clarice Martins Lopes, Faculdade São Francisco da Paraíba (FASP),

Cajazeiras, PB, Brasil.

claralice12@gmail.com

Maria Betânia Alexandre de Barros, Universidade Federal de Campina Grande (UFCG), Cajazeiras, PB, Brasil.

betaniaibcumari@hotmail.com

Joseph Ragner Anacleto Fernandes Dantas, Faculdade São Francisco da Paraíba (FASP),

Cajazeiras, PB, Brasil.

josephragner@gmail.com

PALAVRAS-CHAVE: remição; reintegração social; professor.

\section{INTRODUÇÃO}

Com a aplicação da lei 12.433/2011, que entrou em vigor no dia 29 de julho de 2011, aconteceram modificações no instituto da remição de penas no Brasil, que possibilitaram a diminuição das penas pelo trabalho ou estudo, viabilizando assim a reintegração social do apenado, além de propiciar a diminuição de presos no sistema carcerário. No presente trabalho abordaremos o papel da escola, através da figura do professor, como agente facilitador para promoção desta reintegração social, haja vista que a lei preconiza que as atividades de estudo poderão ser desenvolvidas de forma presencial ou por metodologia de ensino a distância e deverão ser certificadas pelas autoridades educacionais competentes dos cursos frequentados.

\section{METODOLOGIA}

A metodologia empregada direcionou-se a análise de conceitos e a busca de referências publicadas para assimilação e interpretação do tema estudado. Assim proporcionou a relação dos dados literários que se transformaram em conhecimento, através da correlação entre os mesmos. A metodologia se apresenta como básica (natureza), 
qualitativa (abordagem do problema), exploratória (objetivo), pesquisa bibliográfica (procedimento técnico).

\section{DESCRIÇÕES, RESULTADOS, INTERPRETAÇÕES...}

A maior dificuldade enfrentada pelos apenados seja durante a execução penal, seja no pós cumprimento da pena, diz respeito a ressocialização, uma vez que a exclusão social é o gargalo de um sistema discriminatório e inoperante. Neste sentido a legislação pertinente abre espaço, para modificação deste quadro. Já que o preso pode remir sua pena através do estudo, conforme a lei de execução penal:

Art. 126. O condenado que cumpre a pena em regime fechado ou semiaberto poderá remir, por trabalho ou por estudo, parte do tempo de execução da pena. § 1ํ A contagem de tempo referida no caput será feita à razão de: I - 1 (um) dia de pena a cada 12 (doze) horas de frequência escolar - atividade de ensino fundamental, médio, inclusive profissionalizante, ou superior, ou ainda de requalificação profissional - divididas, no mínimo, em 3 (três) dias;

Referido artigo, exposta que para o apenado que venha a cursar, a cada 12 horas de atividades escolares, será computado um dia de pena, onde as atividades podem ser dividias em até três dias, diminuindo assim, sensivelmente a pena e possibilitando reingresso do apenado na sociedade, bem como promovendo a participação e interação com atividades educacionais que promovem o afastamento do ambiente destrutível dos presídios.

Para Barros (2001, p.184), a remição é uma forma de individualização da pena que tende a diminuir a severidade da intervenção penal e reduzir os efeitos negativo da pena privativa de liberdade, ao possibilitar a volta mais rápida do preso ao convívio social. Assim efetivando a ressocialização do preso, além de ser um benefício para o sistema carcerário, no sentido de diminuição da superlotação nos presídios.

Neste sentido, a bonificação utilizada pela lei, serve como incentivo e instrumento para que o professor, consiga estimular o desenvolvimento das atividades escolares, no processo de ensino aprendizagem. Introduzindo pensamentos como de Paulo Freire, "se o meu compromisso é realmente com o homem concreto, com a causa de sua humanização, de 
sua libertação, não posso por isso mesmo prescindir da ciência, nem da tecnologia, com as quais me vou instrumentando para melhor lutar por esta causa” (2007, p. 22).

Para Freire, O educador é um "realizador de sonhos", aqui o papel do educador figura além das questões utópicas, pois através da escola a liberdade será efetivada não em seu sentido figurado, mas sim em sua literalidade. Desta forma o professor tem em suas mãos a possibilidade, de transformar e resgatar a dignidade da pessoa humana, bem como inseri-lo na sociedade, como sujeito de direitos e obrigações.

Nesse contexto o educador consegue não só promover uma modificação na assimilação do conhecimento, mas na formação cidadã, estimulando o apenado para agir, mudar, criar, criticar, cooperar, fazendo nascer o estimulo a uma nova perspectiva de futuro.

\section{CONSIDERAÇÕES FINAIS}

Diante do exposto, nota-se que o papel do professor para aplicação do instituto da remição, no que concerne a sua efetivação prática, é essencial. Pois através da motivação para o cumprimento da pena, o educador pode incutir no detento, o poder transformador do conhecimento, modificando assim a concepção do apenado e assegurando a ressocialização.

\section{REFERÊNCIAS}

BRASIL. Lei de Execução Penal - lei nº 7.210, de 11 de julho de 1984. Brasília: Ministério da Justiça, 1984.

BARROS, Carmen Silva de Moraes. A individualização da pena na Execução Penal. São Paulo: Revista dos Tribunais, 2001.

MAFRA, Jason Ferreira. A conectividade radical como princípio e prática da educação em Paulo Freire. Tese de doutorado. São Paulo: FE/USP. (2007) 